\title{
EFISIENSI PUPUK POSFAT AKIBAT KOMBINASI INOKULASI MIKORIZA ARBUSKULA (FMA)-SP- 36TERHADAP ARSITEKSTUR AKAR KELAPA SAWIT (Elaeis quineensis Jacq) DI MAIN NURSERY
}

\author{
SRI UTAMI LESTARI ${ }^{1}$, MURYANTO $^{1}$, ENNY MUTRYARNY $^{1}$ \\ ${ }^{1}$ Prodi Agroteknologi Fakultas Pertanian Universitas Lancang Kuning \\ Jl.Yos Sudarso Km.8 Rumbai-Pekanbaru \\ Email : uut76solo@gmail.com
}

\begin{abstract}
ABSTRAK
Penelitian ini bertujuan untuk mengetahui pengaruh kombinasi Fungi Mikoriza Arbuskula (FMA) - Pupuk SP-36 terhadap pertumbuhan tanaman kelapa sawit (Elaeis guineensis Jacq) di main nursery. Rancangan yang digunakan pada penelitian ini disusun dalam Rancangan Acak Lengkap (RAL) non faktorial, yang terdiri dari 9 (sembilan) taraf dan3 (tiga) ulangan. Data hasil pengamatan dianalisis dengan menggunakan sidik ragam, apabila F hitung $\geq$ F table 5\% maka dilakukan uji lanjut dengan Duncant Multiple Range Test (DMRT) pada taraf $5 \%$. Parameter yang diamati dalam penelitian ini adalah tinggi tanaman $(\mathrm{cm})$, jumlah daun (helai), panjang akar $(\mathrm{cm})$, jumlah akar lateral (helai), luas daun $\left(\mathrm{cm}^{2}\right)$ dan diameter batang (cm), arsitektur akar, serapan P. Hasil penelitian menunjukkan bahwa pemberian kombinaSI FMA dan Pupuk SP-36 berpengaruh bernyata terhadap tinngi tanaman, luas daun dan panjang akar, namun tidak berpengaruh nyata terhadap parameter jumlah daun, dan jumlah akar lateral. Hasil terbaik pemberian kombinasi FMA dan Pupuk SP-36 terdadap ada taraf perlakuan $\mathbf{M}_{4}$ dengan dosis FMA 15 gram/polybag dan dosis 2,25 gram/polybag. Kombinasi antara inokulasi FMA dan Pupuk SP-36 mempengaruhi arsitektur akar bibit kelapa sawi di main nursery, Kombinasi antara inokulasi FMA dan Pupuk SP-36 mempengaruhi serapan P tanaman kelapa sawit di main nursery
\end{abstract}

Kata Kunci :arsitektur,kelapa sawit,mikoriza, serapan P,SP-36

Diterima: 1 Juni 2018, disetujui: 21 Juli 2018.

\section{PENDAHULUAN}

Kelapa sawit (Elaeis quineensis Jacq) merupakan tanaman palma yang termasuk komoditi andalan di sektor perkebunan .Hal ini dikarenakan permintaan minyak sawit yang semakin meningkat, selain itu sebagai salah satu komoditi andalan ekspor non migas. Tanaman kelapa sawit saat ini merupakan salah satu jenis tanaman perkebunan yang menduduki posisi penting di sektor pertanian disebabkan kelapa sawit dapat menambah devisa dan menciptakan lapangan kerja.

Khusus untuk perkebunan sawit ini permasalahan umum yang dihadapi antara lain rendahnya produktivitas dan mutu produksinya. Dengan luas areal perkebunan kelapa sawit di Indonesia pada tahun 2012 adalah 9.074.621 $\mathrm{Ha}$ dengan total produksi 23.521.071 ton CPO, meningkat $1.84 \%$ dari produksi di tahun 2011 (Direktorat Jenderal 
Perkebunan, 2012). Meskipun mengalami peningkatan, namun produktivitas kebun kelapa sawit di Indonesia rata-rata hanya mampu menghasilkan 16 ton Tandan Buah Segar (TBS)/ha/tahun, sementara potensi produksi bila menggunakan bibit unggul bisa mencapai 30 ton TBS/ha/tahun(Sunarko, 2010 dalam Gede, 2015). Produktivitas yang tinggi merupakan impian yang sangat diinginkan oleh para pengusaha kelapa sawit, karena hal tersebut akan meningkatkan keuntungan bagi mereka.

Melihat permasalahan ini perlu dilakukan upaya untuk meningkatkan produktivitas dan mutu produksinya, untuk memperoleh hasil tersebut,peningkatan dapat dilakukan dengan perbaikan mutu di pembibitan dan juga pemupukan karena pembibitan memiliki peran yang sangat penting untuk menghasilkan tanaman kelapa sawit yang baik dan bermutu.

Usaha untuk memperbaiki kualitas bibit tanaman kelapa sawit mempunyai efek yang terhadap pertumbuhan tanaman selanjutnya, untuk itu sangat diperlukan pengetahuan didalam pembibitan, sehingga bibit yang dihasilkan berkualitas. Selama pembibitan media tumbuh harus dapat menyediakan zat hara optimal, sehingga bibit dapat tumbuh semestinya. Pembibitan kelapa sawit di main-nursery juga sebagai tolak ukur keberhasilan pertumbuhan tanaman dilapangan. Penyediaan bibit yang baik dan sehat selama di pembibitan juga merupakan titik awal yang paling menentukan masa depan pertumbuhan kelapa sawit.

Ketersediaan unsur hara merupakan factor lingkungan yang sangat penting dalam mempengaruhi pertumbuhan bibit kelapa sawit. Sementara Propinsi Riau banyak di dominasi oleh tanah Podzolik Merah Kuning (PMK) yang memilikitingkatkesuburan tanahnya rendah, mempunyai sifat asam dengan kelarutan unsur aluminiumdan besi tinggi yang cenderung mengikat ion fosfat menjadi fosfat tidak larut dan tidak tersedia bagi tanaman. Maka dari itu upaya untuk meningkatkan unsur $\mathrm{P}$ didalam tanah adalah dengan melakukan pemupukan P.Jenis pupuk yang dapat menambah unsur $\mathrm{P}$ dalam tanah antara lain pupuk Super Phosphate 36 (SP-36).

Mengingat semakin meningkatnya harga pupuk buatan dan ditambah dengan kebijakan pemerintah yang menghapus sistem subsidi pupuk, menjadi salah satu permasalahan ekonomi untuk mendapatkan pupuk tersebut bagi para petani. Apabila dilihat dari persediaan bahan baku yang tidak dapat diperbaharui, bahan baku pembuatan pupuk posfor semakin hari semakin menipis dan semakin besar kemungkinan terjadi kelangkaan bahan baku.

Untuk itu, dalam mengefisiensi pemupukan khususnya $\mathrm{P}$ dan menyediakan hara bagi tanah dan tanaman, maka perlu dikembangkan bioteknologi tanah, yaitu salah satu contohnya pemanfaatan fungi atau cendawan yang berperan dalam menyediakan unsur hara $\mathrm{P}$ di dalam tanah yang dikenal dengan Fungi Mikoriza Arbuskula (FMA). Fungi Mikoriza Arbuskula (FMA) adalah suatu bentuk hubungan simbiosis mutualisme antara fungi atau cendawan dengan perakaran tanaman tingkat tinggi yang dapat membantu penyedia unsur hara, terutama unsur hara phospat $(\mathrm{P})$.

Efisiensi mikoriza pada tanaman dipengaruhi oleh jumlah inokulum yang diberikan dalam proses penginfeksian. Semakin banyak inokulan yang diberikan, maka kemungkinan akar tanaman terinfeksi akan semakin tinggi. Berdasarkan uraian diatas penulis tertarik untuk melakukan penelitian yang berjudul "Efisiensi Pupuk Posfat Akibat Kombinasi Inokulasi Mikoriza Arbuskula (FMA) - 
SP-36Terhadap Arsitekstur Akar Kelapa Sawit (Elaeis guineensis Jacq) Di Main Nursery". Tujuan penelitian adalah untuk mengetahui pengaruh kombinasi Fungi

\section{METODE PENELITIAN}

Penelitian ini dilaksanakan secara eksperimen dengan menggunakan Rancangan Acak Lengkap (RAL) non faktorial, yang terdiri dari 9 (sembilan) taraf dan3 (tiga) ulangan, sehingga terdapat 27 plot percobaan. Tiap plot terdiri dari 3 (tiga) tanaman dan 2 (dua) tanaman dijadikan sampel, sehingga jumlah keseluruhan tanaman $27 \times 3=81$ tanaman. Adapun taraf dari kombinasi perlakuan sebagai berikut : $\mathbf{M}_{0}$ : Tanpa Inokulasi Mikoriza (FMA) dan Tanpa SP36, $\mathrm{M}_{1}$ :Tanpa Inokulasi Mikoriza (FMA) dan Pemberian SP-36 2,25 gr poly ${ }^{1}, \mathrm{M}_{2}$ :Tanpa Inokulasi Mikoriza (FMA) dan Pemberian SP-36 4,5 gr poly-1, $\mathrm{M}_{3}$ : Inokulasi Mikoriza 15 gr poly $^{-1}$ (FMA) dan Tanpa SP-36,M4: Inokulasi Mikoriza 15 gr poly ${ }^{-1}$ (FMA) dan Pemberian SP-36 2,25 gr poly ${ }^{-1}, \mathrm{M}_{5}$ : Inokulasi Mikoriza 15 gr poly ${ }^{-1}$ (FMA) dan Pemberian SP-36 4,5 gr poly ${ }^{-1}, \mathrm{M}_{6}$ : Inokulasi Mikoriza 30 gr poly $^{-1}$ (FMA) dan Tanpa SP-36,M $\mathbf{M}_{7}$ :Inokulasi Mikoriza 30 gr poly $^{-1}$ (FMA) dan Pemberian SP-36 2,25 gr poly $^{-1}, \mathrm{M}_{8} \quad$ : $\quad$ Inokulasi Mikoriza 30 gr/poly (FMA) dan Pemberian SP-36 4,5 gr poly=- 1 .

Data hasil pengamatan yang diperoleh dianalisis secara statistik dengan menggunakan analisis sidik ragam. $F$ Hitung $\geq$ dari $\mathrm{F}$ Tabel maka dilanjutkan dengan uji lanjut Duncan's New Multiple Range Test (DMRT) pada taraf $5 \%$ (Surtinah, 2013)

\section{Perlakuan}

Perlakukan Fungi Mikoriza

Arbuskula (FMA) diberikan sekali aplikasi yaitu pada saat pemindahan bibit ke polybag besar.Pemberian dilakukan
Mikoriza Arbuskula (FMA) - Pupuk SP-36 terhadap pertumbuhan tanaman kelapa sawit (Elaeis guineensis Jacq) di main nursery

dengan menaburkan Fungi Mikoriza Arbuskula (FMA) dilubang tanam bibit.

Perlakukan pupuk SP-36 diberikan sekali aplikasi yaitu pada saat pemindahan tanaman ke polybag besar.Pemberian dilakukan secara tugal mengelilingi batang dengan kedalam $7 \mathrm{~cm}$.

Seluruh pengamatan dilakukan pada akhir penelitian, adapun parameter yang diamati yaitu :

\section{Tinggi Tanaman $(\mathrm{cm})$}

Pengukuran tinggi tanaman dilakukan dengan menggunakan meteran, pengukuran dimulai dari pangkal batang hingga ujung daun terpanjang secara te gak lurus dengan batang.

\section{Jumlah Daun (Helai)}

Jumlah daun yang dihitung adalah semua daun yang telah terbuka sempurna pada tiap tanaman sampel.

\section{Luas Daun $\left(\mathrm{cm}^{2}\right)$}

Pengukuran luas daun, yaitu mengukur daun yang paling luas diantara yang terbuka sempurna. Pengukuran dilakukan terhadap panjang dan lebar dangan rumus $\mathrm{L}=\mathrm{P} \times 1 \times$ 0,57 cm (Lubis, 2000).

\section{Diameter Batang $(\mathrm{cm})$}

Diameter batang diukur dengan menggunakan jangka sorong, yaitu dari sisi pangkal batang.

\section{Panjang Akar (cm)}

Pengukuran panjang akar dilakukan dengan cara membongkar bibit dengan hati-hati, kemudian akar dibersihkan dari sisa-sisa tanah dan diukur mulai dari pangkal akar sampai ujung akar terpanjang dengan menggunakan penggaris.

6. Arsitektur Akar

Pengamatan arsitektur akar dilakukan secara visual dengan cara membentang akar secara lebar dengan 
bantuan papan yang telah dipaku untuk membentangkan akar kemudian diambil fotonya lalu dianalisis arsitekturnya

\section{HASIL DAN PEMBAHASAN}

\section{Tinggi Tanaman $(\mathrm{cm})$}

Hasil analisis sidik ragam memperlihatkan bahwa Pemberian kombinasi FMA dan Pupuk SP-36 berpengaruh nyata terhadap tinggi meliputi pola penyebaran akar serta morfologi akar yang diinokulasi FMA.

Tabel 1. Rerata Tinggi Tanaman (cm) Bibit Kelapa Sawit Akibat Pemberian Ko mbinasi FMA dan Pupuk SP-36

\begin{tabular}{|c|c|}
\hline Perlakuan & Rerata \\
\hline $\mathrm{M}_{0}=$ Tanpa pemberian FMA dan Tanpa SP-36 & 39,93 a \\
\hline $\mathbf{M}_{1}=$ Tanpa pemberian FMA dan SP-36 2,25 g polybag $^{-1}$ & $46,00 \mathrm{~b}$ \\
\hline $\mathrm{M}_{2}=$ Tanpa pemberian FMA dan SP-36 4,5 $\mathrm{g}$ polybag $^{-1}$ & $48,30 \mathrm{~b}$ \\
\hline $\mathrm{M}_{3}=$ Pemberian FMA $15 \mathrm{~g}_{\text {polybag }}{ }^{-1}$ dan Tanpa SP-36 & $45.48 \mathrm{~b}$ \\
\hline $\mathrm{M}_{4}={\text { Pemberian FMA } 15 \mathrm{~g} \text { polybag }}^{-1}$ dan SP-36 2,25 $\mathrm{g} \mathrm{polybag}^{-1}$ & $55,55 \mathrm{c}$ \\
\hline 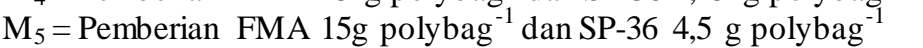 & $47,20 \mathrm{~b}$ \\
\hline $\mathrm{M}_{6}=$ Pemberian FMA 30g polybag ${ }^{-1}$ dan Tanpa SP-36 & $49,72 \mathrm{~b}$ \\
\hline 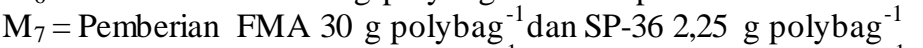 & $48,55 \mathrm{~b}$ \\
\hline 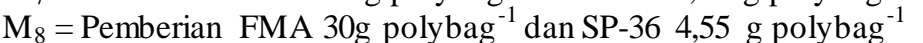 & $50,43 \mathrm{~b}$ \\
\hline
\end{tabular}

Keterangan : Angka-angka yang diikuti oleh huruf yang sama artinya berbeda tidak nyata menurut uji lanjut DMRT pada taraf $5 \%$.

Pada tabel diatas hasil uji lanjut DMRT 5\% bahwa pada taraf perlakuan $\mathrm{M}_{4}$ dengan dosis FMA 15 g/polybag dengan SP-36 2,25 g/polybag memberikan tinggi tanaman terbaik dan berbeda nyata dengan semua taraf perlakuan. Rerata tinggi tanaman terbaik pada taraf $\mathrm{M}_{4}$ sebesar $55,55 \mathrm{~cm}$, sedangkan terendah terlihat pada perlakuan $\mathrm{M}_{0}$ yaitu $39,93 \mathrm{~cm}$.

\section{Jumlah Daun (Helai)}

Hasil analisis sidik ragam mnunjukkan bahwa pemberian kombinasi tanaman bibit kelapa sawit main nursery, sedangkan rerata tinggi tanaman dapat dilihat pada tabel 1 di bawah ini.

Tabel 2. Rerata Jumlah Daun (Helai) Bibit Kelapa Sawit Akibat Pemberian Komb inasi FMA dan Pupuk SP-36

\begin{tabular}{|c|c|}
\hline Perlakuan & Rerata \\
\hline $\mathrm{M}_{0}=$ Tanpa pemberian FMA dan Tanpa SP-36 & 9,33 \\
\hline $\mathrm{M}_{1}=$ Tanpa pemberian FMA dan SP-36 2,25 g polybag $^{-1}$ & 9,33 \\
\hline $\mathrm{M}_{2}=$ Tanpa pemberian FMA dan SP-36 4,5 $\mathrm{g}$ polybag $^{-1}$ & 10,50 \\
\hline $\mathrm{M}_{3}=$ Pemberian FMA $15 \mathrm{~g}$ polybag $^{-1}$ dan Tanpa SP-36 & 10,60 \\
\hline $\mathrm{M}_{4}=$ Pemberian FMA $15 \mathrm{~g}$ polybag $^{-1}$ dan SP-36 $2,25 \mathrm{~g}_{\text {polybag }^{-1}}$ & 10,67 \\
\hline $\mathrm{M}_{5}={\text { Pemberian FMA } 15 \mathrm{~g} \text { polybag }}^{-1}$ dan SP-36 4,5 $\mathrm{g}_{\text {polybag }}{ }^{-1}$ & 11,00 \\
\hline $\mathrm{M}_{6}=$ Pemberian FMA $30 \mathrm{~g}$ polybag $^{-1}$ dan Tanpa SP-36 & 10,67 \\
\hline $\mathrm{M}_{7}={\text { Pemberian FMA } 30 \mathrm{~g} \text { polybag }}^{-1}$ dan SP-36 2,25 $\mathrm{g}$ polybag $^{-1}$ & 10,83 \\
\hline $\mathrm{M}_{8}={\text { Pemberian FMA } 30 \mathrm{~g} \text { polybag }}^{-1}$ dan SP-36 4,5 $\mathrm{g}$ polybag ${ }^{-1}$ & 10,83 \\
\hline
\end{tabular}

Keterangan: Tidak diuji lanjut DMRT pada taraf $5 \%$. 
Tabel 3. Rerata Luas Daun $\left(\mathrm{cm}^{2}\right)$ Bibit Kelapa Sawit Akibat Pemberian Kombinasi FMA dan Pupuk SP-

\begin{tabular}{|c|c|}
\hline Perlakuan & Rerata \\
\hline M0 = Tanpa pemberian FMA dan Tanpa SP-36 & 178,43 a \\
\hline M1 = Tanpa pemberian FMA dan SP-36 2,25 g polybag $^{-1}$ & $223,41 \mathrm{~b}$ \\
\hline M2 = Tanpa pemberian FMA dan SP-36 4,5 g polybag -1 & $259,02 \mathrm{bc}$ \\
\hline M3 = Pemberian FMA 15 g polybag $^{-1}$ dan Tanpa SP-36 & $235,60 \mathrm{~b}$ \\
\hline M4 = Pemberian FMA $15 \mathrm{~g}$ polybag $^{-1}$ dan SP-36 2,25 g polybag $^{-1}$ & $344,02 \mathrm{e}$ \\
\hline M5 = Pemberian FMA $15 \mathrm{~g}$ polybag $^{-1}$ dan SP-36 $4,5 \mathrm{~g}$ polybag $^{-1}$ & $274,54 \mathrm{~cd}$ \\
\hline M6 $=$ Pemberian FMA $30 \mathrm{~g}$ polybag ${ }^{-1}$ dan Tanpa SP-36 & $250,27 \mathrm{bc}$ \\
\hline M7 = Pemberian FMA $30 \mathrm{~g}$ polybag ${ }^{-1}$ dan SP-36 2,25 g polybag $^{-1}$ & $275,73 \mathrm{~cd}$ \\
\hline M8 = Pemberian FMA 30 g polybag $^{-1}$ dan SP-36 4,5 g polybag $^{-1}$ & 307,79 de \\
\hline
\end{tabular}

Keterangan : Angka-angka yang diikuti oleh hurufyang sama artinya berbeda tidak nyata menurut uji lanjut DMRT pada taraf $5 \%$.

Tabel hasil uji lanjut menunjukkan bahwa pada taraf perlakuan $\mathrm{M}_{4}$ dengan pemberian 15 g/polybag FMA dengan 2,25 g/polybag SP-36 memberikan hasil terbaik yang berbeda nyata terhadap semua taraf perlakuan, namun tidak berbeda nyata denga taraf perlakuan $\mathrm{M}_{8}$. Hasil rerata tertinggi terdapat pada $\mathrm{M}_{4}$ yaitu $344,02 \mathrm{~cm}^{2}$ dan terendah pada $\mathrm{M}_{0}$ yaitu $178,42 \mathrm{~cm}^{2}$.

\section{Diameter Batang (cm)}

Hasil analisis sidik ragam
menunjukkan bahwa
kombinasi FMA dan Pupuk

Tabel 4. Rerata Diamater Batang (cm) Bibit Kelapa Sawit Akibat Pemberian Ko mbinasi FMA dan Pupuk SP-36

\begin{tabular}{|c|c|}
\hline Perlakuan & Rerata \\
\hline M0 = Tanpa pemberian FMA dan Tanpa SP-36 & $2,68 \mathrm{a}$ \\
\hline M1 = Tanpa pemberian FMA dan SP-36 2,25 g polybag $^{-1}$ & $2,95 a b c$ \\
\hline $\mathrm{M} 2=$ Tanpa pemberian FMA dan SP-36 4,5 $\mathrm{g}$ polybag $^{-1}$ & $3,00 \mathrm{bc}$ \\
\hline M3 $=$ Pemberian FMA $15 \mathrm{~g} \mathrm{polybag}^{-1}$ dan Tanpa SP-36 & $2,90 \mathrm{ab}$ \\
\hline M4 = Pemberian FMA $15 \mathrm{~g}$ polybag $^{-1}$ dan SP-36 2,25 $\mathrm{g} \mathrm{polybag}^{-1}$ & $3,32 \mathrm{~d}$ \\
\hline M5 $=$ Pemberian FMA $15 \mathrm{~g}$ polybag $^{-1}$ dan SP-36 4,5 $\mathrm{g}$ polybag $^{-1}$ & $2,87 \mathrm{ab}$ \\
\hline M6 $=$ Pemberian FMA $30 \mathrm{~g}$ polybag $^{-1}$ dan Tanpa SP-36 & $3,12 \mathrm{bcd}$ \\
\hline M7 = Pemberian FMA $30 \mathrm{~g}$ polybag $^{-1}$ dan SP-36 2,25 $\mathrm{g} \mathrm{polybag}^{-1}$ & $3,08 \mathrm{bcd}$ \\
\hline M8 $=$ Pemberian FMA $30 \mathrm{~g}$ polybag $^{-1}$ dan SP-36 $4,5 \mathrm{~g} \mathrm{polybag}^{-1}$ & $3,22 \mathrm{~cd}$ \\
\hline
\end{tabular}

Keterangan : Angka-angka yang dikuti oleh yang sama artinya berbeda tidak nyata menurut uji lanjut DMRT pada taraf $5 \%$.

Pada tabel diatas hasil uji lanjut DMRT 5\% menunjukkan bahwa pada taraf perlakuan $\mathrm{M}_{4}$ dengan pemberian 15 g/polybag FMA dengan 2,25 g/polybag SP-36 memberikan hasil terbaik yang berbeda nyata terhadap semua taraf perlakuan, tetapi tidak berbeda nyata dangan taraf $\mathbf{M}_{6}, \mathrm{M}_{7}$ dan $\mathrm{M}_{8}$. Hasil rerata tertinggi terdapat pada $\mathrm{M}_{4}$ yaitu 3,32 $\mathrm{cm}$ dan terendah pada $\mathrm{M}_{0}$ yaitu $2,68 \mathrm{~cm}$.

\section{Panjang Akar (cm) \\ Pada analisis sidik ragam menunjukkan bahwa pemberian kombinasi FMA dan Pupuk SP-36 berpengaruh nyata terhadap panjang akar bibit kelapa sawit di main nursery, untuk rerata panjang akar bibit kelapa sawit disajikan pada tabel 5 di bawah ini :}


Tabel 5. Rerata Panjang Akar (cm) Bibit Kelapa Sawit Akibat Pemberian Kombinasi FMA dan Pupuk SP-36

\begin{tabular}{|c|c|}
\hline Perlakuan & Rerata \\
\hline M0 = Tanpa pemberian FMA dan Tanpa SP-36 & $33,80 \mathrm{a}$ \\
\hline M1 = Tanpa pemberian FMA dan SP-36 2,25 g polybag $^{-1}$ & $37,10 \mathrm{ab}$ \\
\hline M2 = Tanpa pemberian FMA dan SP-36 4,5 g polybag $^{-1}$ & $40,80 \mathrm{bc}$ \\
\hline M3 = Pemberian FMA 15 g polybag $^{-1}$ dan Tanpa SP-36 & $39,47 \mathrm{bc}$ \\
\hline M4 = Pemberian FMA $15 \mathrm{~g}$ polybag $^{-1}$ dan SP-36 2,25 g polybag $^{-1}$ & $44,73 \mathrm{c}$ \\
\hline M5 = Pemberian FMA $15 \mathrm{~g}$ polybag $^{-1}$ dan SP-36 4,5 $\mathrm{g}^{\text {polybag }}{ }^{-1}$ & $42,77 \mathrm{bc}$ \\
\hline M6 = Pemberian FMA $30 \mathrm{~g}$ polybag $^{-1}$ dan Tanpa SP-36 & $41,07 \mathrm{bc}$ \\
\hline M7 = Pemberian FMA $30 \mathrm{~g}$ polybag ${ }^{-1}$ dan SP-36 2,25 g polybag $^{-1}$ & $42,55 \mathrm{bc}$ \\
\hline M8 = Pemberian FMA $30 \mathrm{~g}$ polybag $^{-1}$ dan SP-36 4,5 $\mathrm{g}$ polybag $^{-1}$ & $44,33 \mathrm{c}$ \\
\hline
\end{tabular}

Keterangan : Angka-angka yang diikuti oleh huruf yang sama artinya berbeda tidak nyata menurut uji lanjut DMRT pada taraf $5 \%$.

Pada tabel diatas hasil uji lanjut DMRT $5 \%$ bahwa pada taraf perlakuan $\mathrm{M}_{4}$ dengan dosis FMA $15 \mathrm{~g} /$ polybag dengan SP-36 2,25 g/polybag memberikan panjang akar terbaik dan berbeda nyata dengan semua taraf perlakuan $\mathrm{m} 0$ dan $\mathrm{m} 1$, namun tidak berbeda nyata dengan taraf perlakuan $\mathrm{M}_{2}$, $\mathrm{M}_{3}, \mathrm{M}_{5}, \mathrm{M}_{6}, \mathrm{M}_{7}$ dan $\mathrm{M}_{8}$. Rerata panjang akar tanaman terbaik pada taraf $\mathrm{M}_{4}$ sebesar $55,55 \mathrm{~cm}$, sedangkan terendah terlihat pada perlakuan $\mathbf{M}_{0}$ yaitu 39,93 $\mathrm{cm}$.

Hasil analisis data sidik ragam menunjukkan bahwa pemberian FMA dan pupuk SP-36 menunjukkan pengaruh nyata terhadap parameter tinggi bibit, lebar daun, diameter batang dan panjang akar, namun berpengaruh tidak nyata terhadap jumlah daun, dan jumlah akar lateral bibit kelapa sawit di main nursery.

Kombinasi antara kedua perlakuan terhadap keempat parameter diatas (tinggi, lebar daun, diameter batang, dan panjang akar) pada rerata perlakuan bahwa tanpa pemberian FMA dan tanpa pemberian SP-36 $\left(\mathrm{M}_{0} \mathrm{~S}_{0}\right)$ memberikan hasil rerata terendah.Hal ini diduga karena tidak adanya perlakuan FMA dan pupuk SP-36 kedalam media. Media yang digunakan pada penelitian ini adalah tanah PMK, dimana tanah PMK rendah bahan organik dan unsur hara terutama $P$. Kondisi Tanah PMK merupakan tanah yang produktivitas rendah apabila tidak diberi bahan pembenah, rendah unsur hara terutama $\mathrm{P}$, Kekurangan $\mathrm{P}$ pada tanah Ultisol dapat disebabkan oleh kandungan $P$ dari bahan induk tanah yang memang sudah rendah, atau kandungan $\mathrm{P}$ sebetulnya tinggi tetapi tidak tersedia untuk tanaman karena diikat oleh unsur lain seperti Al dan Fe (Sipayung, Sitanggang, Damanik, 2014).

Adanya pengaruh nyata pada tinggi bibit, lebar daun, diameter batang panjang akar akibat pemberian FMA dan SP-36 diduga adanya sinergitas/saling mendukung antara kedua faktor ini, sehingga terjadi peningkatan pertumbuhan bibit kelapa sawit. SP-36 merupakan pupuk sumber hara $\mathrm{P}$ bagi tanaman.Sedangkan FMA merupakan jamur yang bersimbiosis mutualisme dengan akar tanaman yang membentuk hifa-hifa eksternal sehingga mampu mengambil hara yang terfiksasi menjadi unsur yang tersedia bagi tanaman (Setiadi 1999 dalam Nurmasita, dkk 2013).

Fosfor berperan penting pada pertumbuhan dan perkembangan tanaman, berperan dalam proses fotosintesa, metabolisme karbohidrat dan proses transfer energi dalam tubuh tanaman (Handayani dan Ernita, 2008). Fosfor (P) merupakan unsur hara makro utama bagi tanaman yang mempunyai permasalahan dalam ketersediaannya didalam tanah karena adanya fiksasi oleh jerapan $\mathrm{P}$ didalam tanah oleh $\mathrm{Al}, \mathrm{Fe}$, dan Mn (Hutauruk, Simanungkalit, Irmansyah, 2012) 
Permasalahan unsur $\mathrm{P}$ yang kurang tersedia ditanah bisa dipenuhi dengan pemupukan SP-36, yang mengandung $36 \%$ P. Namun, seiring pemakaian terus menerus mengakibatka bahan baku semakin langka dan tentunya akan berdampak terhadap harga yang semakin relatif tinggi sehingga akan semakin susah diperoleh para petani. Pemupukan yang dilakukan setiap musim tanam menyebabkan timbunan $\mathrm{P}$ yang semakin banyak sebagai residu $\mathrm{P}$ tanah (Hutauruk $d k k$ 2012). Teknologi yang saat ini berkembang untuk menekan penggunaan SP-36 dengan FMA.

Fungi Mikoriza Arbuskula merupakan jenis fungi yang menguntungkan pertumbuhan tanaman terutama pada tanah yang mengalami kekurangan fosfor. FMA tidak hanya menguntungkan pertumbuhan tanaman, tetapi juga meningkatkan kebutuhan fosfat 20\% sampai 30\% (Sutanto, 2005 dalam Rivana, Indriani, Khairani, 2016). Peningkatan pertumbuhan dengan adanya pemberian FMA merupakan hal yang diharapkan dari pemasukan teknologi ini. Hal ini di sebabkan karena mikoriza dapat membantu penyerapan unsur hara dengan cara memperluas daerah pengambilan unsur hara sehingga laju pertumbuhan tanaman lebih cepat karena adanya infeksi akar yang menyebabkan bertambahnya bulu-bulu akar. Hal ini sesuai dengan Tirta (2006), FMA adalah sejenis jamur yang bersimbiosis dengan akar tanaman yang mampu meningkatkan serapan unsur hara dan air sehingga mempunyai laju pertumbuhan lebih cepat.

Fungi Mikoriza Arbuskula memiliki struktur hifa yang menjalar luas ke dalam tanah, melampaui jauh jarak yang dapat dicapai oleh rambut akar.Pada saat $\mathrm{P}$ berada disekitar rambut akar, maka hifa membantu menyerap $\mathrm{P}$ di tempat-tempat yang tidak dapat dijangkau rambut akar.Daerah akar bermikoriza tetap aktif dalam mengabsorpsi hara untuk jangka waktu yang lebih lama dibandingkan dengan akar yang tidak bermikoriza. Fungi Mikoriza Arbuskula dalam akar tanaman akan membantu tanaman dalam menyerap unsur hara $\mathrm{P}$ yang tidak tersedia menjadi tersedia bagi tanaman. Peran FMA meningkatkan penyerapan $\mathrm{P}$ dan pertumbuhan, serta meningkatkan hasil tanaman demikian unsur hara yang diserap semakin meningkat (Sartini, 2004).

Salah satu manfaat yang diharapkan dalam pengaplikasian FMA terhadap tanaman adalah fungsinya membantu dalam penyerapan unsur $\mathrm{P}$, selain $\mathrm{P}$ FMA juga dapat meningkatkan serapan hara $\mathrm{N}$ dan $\mathrm{K}$ yang merupakan hara makro tanaman (Teotia, 2017 dalam Margaretha, Syarif dan Nasution, 2017). Terpenuhinya hara-hara untuk tanaman tentunya akan meningkatkan proses fisiologi sehingga terjadi peningkatan pertumbuhan dan perkembangan. Unsur P merupakan hara makro yang harus tersedia dalam pertumbuhan dan perkembangan tanaman.Sementara sifat $\mathrm{P}$ yang bermasalah ditanah PMK yang terjerap oleh Al dan Fe. Dengan penggunaan FMA maka jerapan $\mathrm{P}$ dapat dilepaskan secara kimia dengan produksi asam- asam organik dan secara biologi memproduksi enzim fosfotase (Handoyo dan Hairah, 2007 dalam Sagala, hanafiah, Razali, 2013)

Peranan FMA dalam menekan penggunaan SP-36 ini terlihat pada hasil kombinasi ketempat parameter (tinggi bibit, lebar daun, diameter batang dan panjang akar) bahwa dengan pemberian FMA 15 g/polybag dengan 2,25 g/polybag $\left(\mathrm{M}_{4}\right)$ memberikan hasil terbaik pada keempat parameter, hasil ini lebih baik dari pada dosis anjuran pemupukan SP-36 sebesar 4,5 g/polibag terhadap bibit kelapa sawit di main nursery. Hal ini berarti pemberian FMA dapat mengefisensi pemupukan SP-36 dari rekomendasi pemupukan main nursey 
kelapa sawit terhadap tinggi bibit, luas daun, dan diameter batang.

Peningkatan pemberian taraf perlakuan kombinasi antara FMA dan SP36 menunjukan adanya penurunan setelah perlakuan $\mathrm{M}_{4}$ (FMA 15 g/polybag dan SP-36 2,25 g/polybag) pada parameter tinggi tanaman, luas daun, diameter batang dan panjang akar. Hal ini diduga dengan peningkatan pemberian mikoriza, mka terjadi kompetisi antar fungi baik dari nutrisi dan oksigen, sehingga akan mengurangi kinerja mikoriza dirhizosfer. Raj (2015) menyatakan bahwa meningkatnya jumlah mikoorganisme maka akan meningkatkan aktifitas mikroorganisme didalam tanah. Hal ini mengakibatkan adanya persaingan mikroorganisme dalam hal makanan dan oksigen, sehingga dapat menurunkan pertumbuhan tamanan lebih rendah.Demikian dengan peningkatan pemberian SP-36 yang dikombinasikan dengan mikoriza mengalami penurunan, hal ini diduga semakin meningkatnya ketersediaan unsur hara didalam tanah memberikan pengaruh negative pada perkembangan FMA dimana pemberian pupuk $\mathrm{P}$ dapat menurunkan perkembangbiakan mikoriza. Hal isi sesuai dengan pendapat Smith dan Read (2008 dalam Daras, Sobari, Trisilawati dan Towah, 2015) bahwa peningkatan Pupuk $\mathrm{P}$ akan menurunkan propagul mikoriza seperti spora dan miselium yang efektif.

Penggunaan FMA dan SP-36 memberikan pengaruh tidak nyata terhadap parameter jumlah daun.Parameter jumlah daun berpengaruh tidak nyata, hal ini diduga bahwa jumlah daun setiap komoditas tanaman lebih dipengaruhi sifat genetis. Martoyo (2001) bahwa respon pupuk terhadap jumlah daun pada umumnya kurang memberikan gambaran yang jelas, karena pertumbuhan daun berhungan erat dengan faktor genetik, demikian halnya dengan jumlah akar lateral memberikan hasil tidak adanya kombinasi, kemungkinan diakibatkan faktor genetik.

\section{Arsitektur Akar}

Peng amatan arsitektur akar pada bibit kelapa sawit di main nursery secara visual dengan cara membentangkan akar , menunjukkan bahwa akar tanaman yang diinokulasi FMA mempengaruhi pertumbuhan akar sekunder. Hal ini diduga pengaruh mikoriza dalam mempercepat serapan $\mathrm{P}$ pada tanaman yang diinokuasi FMA. Pertumbuhan akar sekunder ini akan berpengaruh terhadap besarnya kontak akar dengan tanah. Disamping itu lebih banyaknya pembentukan akar lateral diduga disebabkan oleh peningkatan sintesis IBA (Asam Indol Butiral). Lebih lanjut menurut Widiastuti (2003) menerangkan bahwa pemberian FMA Gigaspora margarita mempercepat pembentukan akar sekunder.

Pemberian mikoriza secara keseluruhan mempengaruhi pertambahan akar.Arsitektur perakaran bibit kelapa sawit yang diinokulasi FMA lebih baik dibandingkan dengan bibit yang tidak diinokulasi.Perbaikan perakaran bibit kelasa sawit menghasilkan simbiosis dalam hal peningkatan serapan P. Hasil analisis serapan $\mathrm{P}$ terlihat tanaman yang diinokulasi FMA meningkatkan pertumbuhan perakaran sehingga menyebabkan kemampuan penyerapan $\mathrm{P}$ meningkat. 

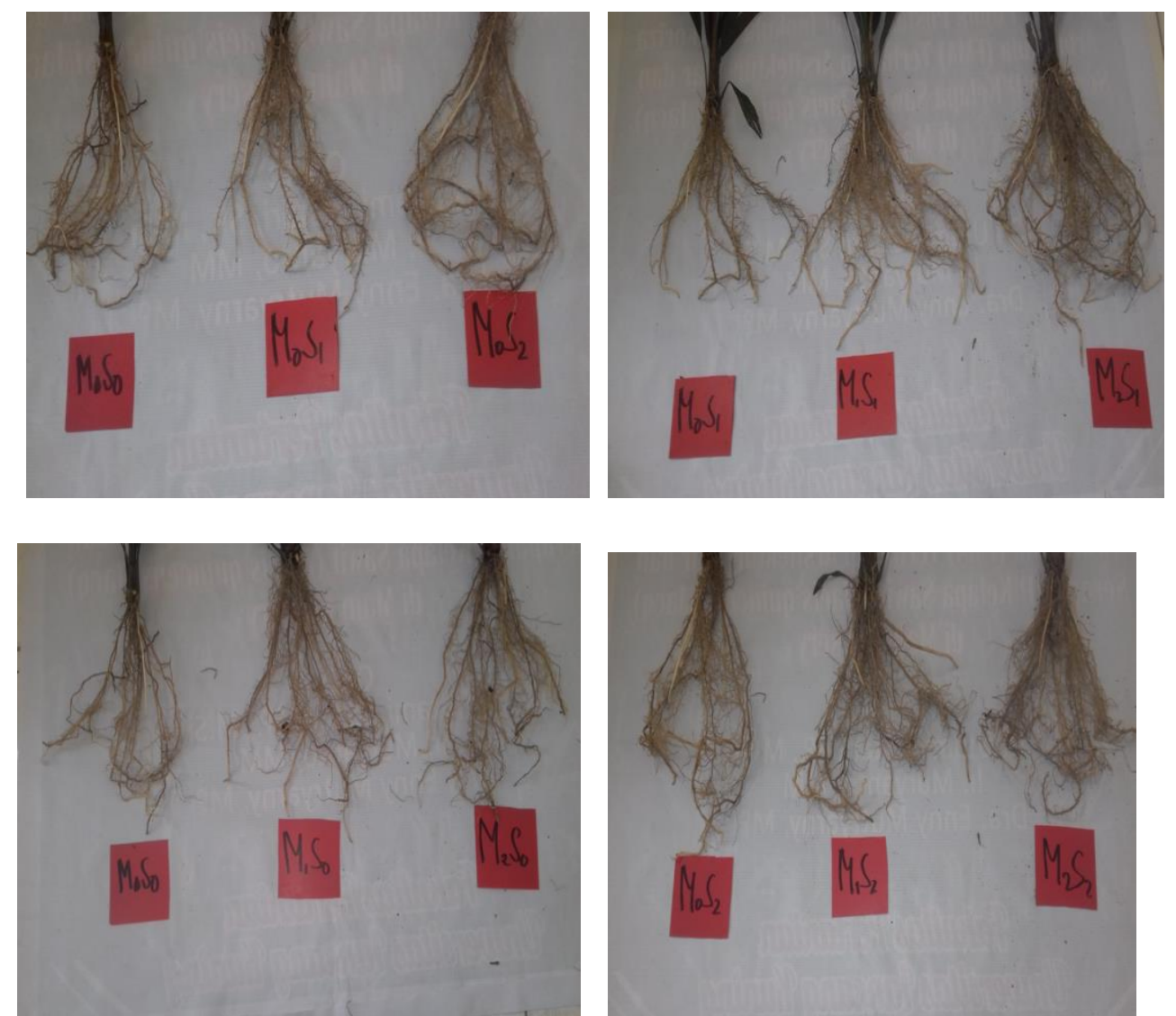

Gambar 1. Perbandingan Arsitektur Akar Bibit Kelapa Sawit Akibat Perlakuan Kombinasi FMA dan SP-36

Tabel 6. Serapan P Pada Tanah, Akar dan Daun Bibit Kelapa Sawit di Main Nursery

\begin{tabular}{|c|c|c|c|}
\hline \multirow[t]{2}{*}{ Perlakuan } & \multicolumn{3}{|c|}{ \% Serapan P } \\
\hline & Tanah & Akar & Daun \\
\hline M0 = Tanpa pemberian FMA dan Tanpa SP-36 & 0,1205 & 0,0960 & 0,0795 \\
\hline M1 = Tanpa pemberian FMA dan SP-36 2,25 g polybag $^{-1}$ & 0,1605 & 0,1225 & 0,1070 \\
\hline M2 = Tanpa pemberian FMA dan SP-36 4,5 g polybag $^{-1}$ & 0,1740 & 0,1420 & 0,1165 \\
\hline M3 = Pemberian FMA 15 g polybag $^{-1}$ dan Tanpa SP-36 & 0,1745 & 0,1365 & 0,1205 \\
\hline M4 = Pemberian FMA $15 \mathrm{~g}$ polybag $^{-1}$ dan SP-36 2,25 $\mathrm{g}$ polybag $^{-1}$ & 0,2495 & 0,1675 & 0,1445 \\
\hline M5 = Pemberian FMA $15 \mathrm{~g}$ polybag $^{-1}$ dan SP-36 $4,5 \mathrm{~g}$ polybag $^{-1}$ & 0,2665 & 0,1970 & 0,1760 \\
\hline M6 = Pemberian FMA $30 \mathrm{~g}$ polybag ${ }^{-1}$ dan Tanpa SP-36 & 0,2485 & 0,1850 & 0,1535 \\
\hline M7 = Pemberian FMA 30 g polybag $^{-1}$ dan SP-36 2,25 g polybag $^{-1}$ & 0,2830 & 0,2365 & 0,1865 \\
\hline M8 = Pemberian FMA $30 \mathrm{~g}$ polybag $^{-1}$ dan SP-36 4,5 $\mathrm{g}^{\text {polybag }}{ }^{-1}$ & 0,3320 & 0,2565 & 0,2270 \\
\hline
\end{tabular}

\section{KESIMPULAN}

Gede Andri Wijaya, Jonatan Ginting dan Haryati, 2015. Respons Pertumbuhan Bibit Kelapa Sawit (Elaeis guineensis Jacq.) di Pre Nurseryterhadap Pemberian Limbah Cair Pabrik Kelapa Sawit dan Pupuk NPKMg (15:15:6:4). Jurnal Online Agroekoteknologi No. 2337- 6597, Vol.3, No.1. Hal $400-415$.
Handayani dan Ernita, 2008.Pemanfaatan Jamur Pelarut Fosfat dan Mikoriza sebagai Alternatif Pengganti Pupuk Fosfat Pada Tanah Ultisol Kabupaten Langkat, Sumatera Utara.Universitas Muslim Nusantara al wasliyah Medan. 
Hutauruk F I, Simanungkalit T, Irmasyah T, 2012. Pengujian Pemberian Fungi Mikoriza Arbuskula Dan Pupuk Fosfat Pada Budidaya Tanaman Sorgum (Sorghum bicolor (L.) Moench).Jurnal Online Agroekoteknologi Vol 1.

Martoyo, K. 2001. Peranan Beberapa Sifat Fisik tanah Ultisol pada Penyebaran Akar Tanaman Kelapa Sawi (Elaeis gueenensis Jacq).Warta Pusat Penelitian Kelapa Sawit.

Nurmasyitah, Syafruddin, dan Muhammad Sayuthi, 2013. Pengaruh Jenis Tanah Dan Dosis Fungi Mikoriza Arbuskular Pada Tanaman Kedelai Terhadap Sifat Kimia Tanah.Jurnal Agrista Vol. 17 No. 3. Hal 103-110.
Sagala, Hanafiah, Razali, 2013) Peranan Mikoriza Terhadap Pertumbuhan, Serapan P Dan Cd Tanaman Sawi (Brassica Juncea L.)Serta Kadar P Dan Cd Andisol Yang Diberi Pupuk Fosfat Alam. Jurnal Online Agroekoteknologi. Vol 2.

Sipayung E S, Sitanggang G, Damanik M M B, 2014. Perbaikan Sifat Fisik Dan Kimia Tanah Ultisol Simalingkar B Kecamatan Pancur Batu Dengan Pemberian Pupuk Organik Supernasa Dan Rockphosphit Serta Pengaruhnya Terhadap Produksi Tanaman Jagung (Zea mays L.). Jurnal Online Agroekoteknologi Vol 2 